\title{
DAYA SERAP AIR DAN KANDUNGAN SERAT (FIBER CONTENT) KOMPOSIT POLIESTER TIDAK JENUH (UNSATURATED POLYESTER) BERPENGISI SERAT TANDAN KOSONG SAWIT DAN SELULOSA
}

\author{
Michael", Elmer Surya, Halimatuddahliana \\ Departemen Teknik Kimia, Fakultas Teknik, Universitas Sumatera Utara, \\ Jl. Almamater Kampus USU Medan 20155, Indonesia \\ *Email : trainsigma@students.usu.ac.id
}

\begin{abstract}
Abstrak
Penelitian ini bertujuan untuk mengetahui pengaruh komposisi pengisi serat tandan kosong sawit dan selulosa terhadap daya serap air dan kandungan serat komposit poliester tidak jenuh. Komposit dibuat dengan metoda hand-lay up dengan mencampurkan poliester tidak jenuh dengan serat tandan kosong sawit dan selulosa dengan komposisi pengisi masing-masing 5, 10, 15, dan 20 (\%b/b). Parameter yang digunakan yaitu penyerapan air setiap 24 jam untuk tiap sampel komposit hingga penyerapan air pada komposit konstan dan diukur kandungan serat pada tiap komposit. Hasil yang didapat yaitu peningkatan daya serap air untuk setiap peningkatan komposisi dari pengisi serat tandan kosong sawit dan selulosa serta kandungan serat yang semakin meningkat sejalan dengan meningkatnya kandungan bahan pengisi
\end{abstract}

Kata kunci: poliester tidak jenuh, serat tandan kosong sawit, selulosa, penyerapan air

\begin{abstract}
This study was aimed to investigate the effect of empty fruit bunch palm oil and cellulose content as filler in water absorption and fibre volume fraction of the unsaturated polyester composites. The composites were made by hand-lay up method by mixing unsaturated polyester with the composition of each fillers (empty fruit bunch palm oil and cellulose) of 5,10,15,20 wt\%. The parameter which was carried on the prepared samples was water absorption for each sample every 24 hours until the composites have constant absorption. It was found that the addition of fillers to the matrix caused the water absorption of composites increased at each of composition of fillers (empty fruit bunch palm oil and cellulose) and the fibre volume fraction increased as the filler content increase.
\end{abstract}

Keywords: unsaturated polyester, empty fruit bunch palm oil,cellulose,water absorption

\section{Pendahuluan}

Penggunaan bahan pengisi alami dalam pembuatan komposit berkembang dengan sangat pesat. Hal ini dikarenakan bahan pengisi alami memiliki keunggulan dibandingkan bahan pengisi non alami seperti modulus dan kekuatan spesifik yang baik, harga ekonomis, densitas rendah, pemrosesan yang lebih sederhana dan memiliki daya biodegradasi [5]. Beberapa bahan pengisi alami seperti kulit biji coklat, kulit pisang dan kulit kelapa pernah digunakan dalam pembuatan komposit sebagai pengganti untuk pengisi bahan non alam seperti serat gelas dan serat karbon [6,12-13,19]. Komposit polimer komersil pada umumnya menggunakan resin termoset sebagai matriks karena penggunaannya yang lebih cocok untuk bidang struktural. Resin termoset biasanya terdiri dari campuran cairan dengan bahan yang memiliki massa molar rendah seperti monomer atau prepolimer yang akan terpolimerisasi ketika dipanaskan untuk membentuk jaringan sambung silang (crosslink) [3]. Diantara semua jenis resin termoset, jenis yang paling umum digunakan yaitu poliester tidak jenuh (Unsaturated Polyester) UPR) karena memiliki sifat penyusutan yang rendah, dapat dicetak pada suhu ruangan, viskositas yang sangat rendah, ketahanan termal dan cuaca yang baik serta biayanya yang murah. Bahan alam lain yang dapat dijadikan pengisi adalah serat tandan kosong sawit. Produksi sawit di Indonesia merupakan yang paling tinggi di dunia sehinga terdapat pula produk samping dari sawit yaitu tandan kosong kelapa sawit yang jadinya sangat tinggi juga $[4,7,17-18,21]$. Tandan kosong kelapa sawit bila diolah lebih lanjut dapat dibuat menjadi serat selulosa yang dapat dijadikan sebagai pengisi alami pada komposit poliester tidak jenuh. Dalam penelitian ini akan dikaji seberapa besar daya serap air pada komposit pengisi serat tandan kosong sawit dan selulosa. Kemudian akan dikaji juga hubungan antara fraksi volume serat terhadap penyerapan air pada komposit. 


\section{Teori}

Unsaturated Polyester Resin (UPR) merupakan sebuah makromolekul dengan adanya gugus poliester dan tergolong kategori resin termoset dimana resin ini merupakan produk dari reaksi tahap demi tahap (step-growth) antara asam jenuh seperti asam phtalat atau isophtalat dengan asam tidak jenuh seperti asam maleat atau fumarat yang dikondensasikan dengan alkohol dihidris [21]. UPR berupa resin cair dengan viskositas yang cukup rendah, mengeras pada suhu kamar dengan penggunaan katalis tanpa menghasilkan gas sewaktu pengesetan seperti banyak resin termoset lainnya. Tandan kosong kelapa sawit merupakan limbah padat lignoselulosa yang dihasilkan dari industri perkebunan kelapa sawit memiliki kandungan serat, komposisi bahan organik dan mineral yang cukup tinggi. Oleh karena itu tandan kosong kelapa sawit dapat dimanfaatkan sebagai bahan baku bagi industri seperti industri pulp dan kertas atau industri kimia lainnya yang memanfaatkan bahan baku berbasis serat [20]. Penelitian tentang penggunaan serat tandan kosong sawit (STKS) sebagai pengisi pada matriks poliester tidak jenuh pernah dilakukan sebelumnya $[8,15]$. Selulosa merupakan polimer dengan berat molekul tinggi yang tersusun oleh unit-unit anhidroglukosa yang terikat satu sama lain dengan ikatan $\beta$-glukosida yang membentuk rantai ikatan panjang dan tidak bercabang. Selulosa memiliki ikatan hidrogen antar rantainya yang menyebabkan selulosa sukar untuk dihidrolisis. Selulosa memiliki rumus kimia $\left(\mathrm{C}_{6} \mathrm{H}_{10} \mathrm{O}_{5}\right)_{\mathrm{n}}$ dengan $\mathrm{n}$ adalah jumlah pengulangan unit-unit gula atau ukuran rantai polimer yang dinyatakan dengan derajat polimerisasi (DP). Molekul-molekul selulosa seluruhnya berbentuk linier dan mempunyai kecendrungan kuat membentuk ikatan hidrogen intra dan intermolekular [1]. Penelitian tentang penggunaan selulosa sebagai pengisi pada matriks poliester tidak jenuh pernah dilakukan sebelumnya [10-11,14]. Adapun penggunaan pengisi serat tandan kosong sawit dan selulosa juga pernah dilakukan pada matriks low density polyethylene (LDPE) [19]. Menurut Lokantara dan Suardana [9], penyerapan air (water-absorption) dalam komposit merupakan kemampuan komposit dalam menyerap uap air dalam waktu tertentu. Daya serap air pada komposit merupakan salah satu masalah terutama dalam penggunaan komposit di luar ruangan. Semua komposit polimer akan menyerap air jika berada di udara lembab atau ketika polimer tersebut dicelupkan di dalam air. Penyerapan air pada komposit berpenguat serat alami memiliki beberapa pengaruh yang merugikan dalam sifatnya dan mempengaruhi kemampuannya dalam jangka waktu yang lama juga penurunan secara perlahan dari ikatan antar muka komposit serta menurunkan sifat mekanis komposit seperti kekuatan tariknya.

\section{Metodologi Penelitian \\ Bahan dan Alat}

Bahan yang digunakan adalah poliester tidak jenuh (UPR), serat tandan kosong sawit (STKS), dan selulosa sebagai bahan baku. Alat utama yang digunakan adalah kaca sebagai wadah pembuatan komposit, malam sebagai wadah cetakan komposit, Beaker glass sebagai wadah untuk penyerapan air komposit, dan timbangan digital untuk mengukur massa komposit.

\section{Proses Pembuatan Komposit UPR-STKS dan UPR-Selulosa}

Resin poliester tidak jenuh sebagai matriks dicampurkan dengan pengisi baik STKS maupun selulosa dengan perbandingan 95:5, 90:10, 85:15, dan 80:20 (b/b) ke dalam Beaker glass. Campuran diaduk perlahan-lahan selama 5 menit hingga merata. Ditambahkan katalis metil etil keton peroksida (MEKP) sebesar 5 tetes pipet untuk setiap 15,15 gram matriks atau bila dikonversikan dalam fraksi volume katalis yang ditambahkan sebesar 5 tetes pipet untuk setiap 18,41 ml [21]. Campuran diaduk selama 2 menit. Alas cetakan kaca terlebih dahulu diberikan bahan pelicin seperti gliserin ataupun kit mobil agar resin tidak melekat pada cetakan. Dituangkan campuran bahan ke dalam cetakan yang sudah disiapkan dari malam (lilin mainan) dan kaca yang telah dibentuk sesuai standar ASTM D-570 dengan ukuran sampel $25 \mathrm{~mm}$ x $25 \mathrm{~mm}$. Ratakan permukaan campuran pada cetakan.Tunggu hingga kering selama 24 jam. Komposit yang sudah kering dilepas dari cetakan kemudian bagian dihaluskan bagian-bagian permukaannya dengan alat kikir dan amplas. Dilakukan prosedur yang sama untuk pengisi selulosa yang berasal dari STKS, dengan variasi perbandingan komposisi yang sama.

\section{Penyerapan Air}

Komposit UPR-STKS dan UPR-selulosa yang telah terbentuk dimasukkan ke dalam oven pada suhu $50 \pm 5^{\circ} \mathrm{C}$ selama 24 jam. Setelah 24 jam, maka komposit didinginkan dalam desikator selama 24 jam. Sebelum pencelupan ke dalam air, komposit terlebih dahulu ditimbang untuk dicatat massa awalnya. Kemudian komposit dicelupkan ke dalam wadah yang berisi air dengan masingmasing wadah memiliki ketinggian air yang sama. Setiap 24 jam komposit diambil dan dibersihkan dengan kertas tisu sampai permukaan komposit betul-betul kering. Komposit yang telah kering ditimbang untuk dicatat penambahan massanya. Prosedur ini dilakukan setiap 24 jam hingga pertambahan massa komposit telah konstan. 
Selanjutnya dihitung persen daya serap air menggunakan persamaan:

$$
\mathrm{Wg}=\frac{\mathrm{We}-\mathrm{Wo}}{\mathrm{Wo}_{0}} \times 100 \%
$$

dimana :

$\mathrm{Wg}=$ Persentase pertambahan berat komposit

$\mathrm{We}=$ Berat komposit setelah perendaman

$\mathrm{Wo}=$ Berat komposit sebelum perendaman

Perhitungan Densitas Komposit

Densitas komposit pada matriks dapat dihitung berdasarkan persamaan-persamaan seperti berikut. Masing-masing komposit ditimbang satu per satu menggunakan timbangan digital untuk dicatat massanya $\left(\mathrm{M}_{\mathrm{C}}\right)$. Patahan komposit dimasukan ke dalam Beaker glass berisi air dengan volume tertentu. Dengan mengunakan pipet tetes diambil volume air yang merupakan volume komposit dari Beaker glass yang naik. Data-data yang diperoleh kemudian digunakan untuk menghitung densitas komposit dengan menggunakan persamaan [16]:

$\rho_{\mathrm{C}}=\frac{\mathrm{M}_{\mathrm{C}}}{\mathrm{V}}$

dimana :

$\rho_{\mathrm{C}}=$ densitas komposit

$\mathrm{M}_{\mathrm{C}}=$ massa komposit

$\mathrm{V} \quad$ = volume komposit

\section{Perhitungan Fraksi Volume Serat dalam Komposit}

Bila densitas resin $\left(\rho_{R}\right)$, dan massa resin $\left(M_{R}\right)$ telah diketahui maka untuk mencari fraksi volume resin $\left(\mathrm{V}_{\mathrm{R}}\right)$ diberikan dalam persamaan berikut:

$$
\begin{aligned}
& \mathrm{V}_{\mathrm{R}}=\frac{\mathrm{M}_{\mathrm{R}}}{\mathrm{M}_{\mathrm{C}}} \frac{\rho_{\mathrm{C}}}{\rho_{\mathrm{R}}} \\
& \text { dimana: } V_{R}=\text { fraksi volume resin } \\
& \mathrm{M}_{\mathrm{R}}=\text { massa resin } \\
& \rho_{\mathrm{R}} \quad=\text { densitas resin }
\end{aligned}
$$

Maka untuk menghitung fraksi massa serat $\left(\mathrm{V}_{\mathrm{F}}\right)$ dan densitas serat $\left(\rho_{\mathrm{F}}\right)$ dihitung berdasarkan persamaan berikut [12]:

$$
\begin{aligned}
& \mathrm{V}_{\mathrm{F}}=1-\mathrm{V}_{\mathrm{R}} \\
& \rho_{\mathrm{F}}=\frac{\mathrm{M}_{\mathrm{F}}}{\mathrm{M}_{\mathrm{C}}} \frac{\rho_{\mathrm{I}}}{\mathrm{V}}
\end{aligned}
$$

dimana :

$\mathrm{V}_{\mathrm{F}} \quad$ = fraksi volume serat

$\mathrm{M}_{\mathrm{F}}=$ massa serat

$\rho_{\mathrm{F}} \quad=$ densitas serat

\section{Hasil dan Pembahasan}

\section{Pengaruh Kandungan Pengisi Terhadap Daya Serap Air}

Hubungan daya serap air terhadap waktu ditunjukkan pada Gambar 1. dimana penyerapan air terbesar untuk semua komposit terjadi pada 24 jam pertama dan ditunjukkan pada komposisi UPR-selulosa 80:20. Dari Gambar 1 dapat dilihat bahwa penyerapan air bahan komposit akan semakin meningkat dengan penambahan kandungan bahan pengisi.

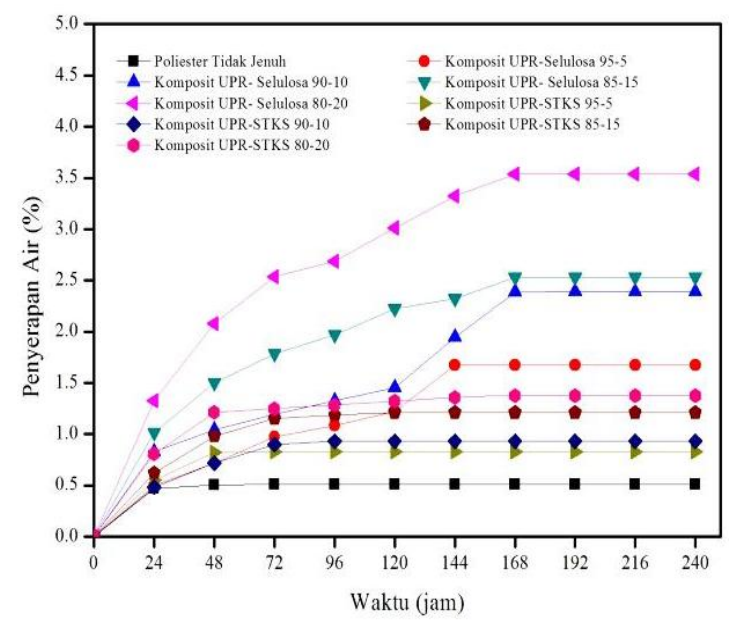

Gambar 1. Penyerapan Air Komposit Terhadap Waktu Perendaman

Penyerapan air terbesar terjadi pada 24 jam pertama, kemudian diikuti oleh 48 dan 72 jam. Setelah itu, maka penyerapan air bahan komposit terlihat tidak begitu signifikan lagi. Hal ini berarti bahwa penyerapan air maksimum bahan komposit terjadi pada 24 jam pertama. Dari Gambar 1 di atas juga dapat dilihat bahwa daya serap air untuk serat tandan kosong sawit lebih kecil dibandingkan dengan selulosa. Hal ini dikarenakan sifat hidrofilik komposit berpengisi STKS hasil tidak begitu besar dibandingkan komposit berpengisi selulosa. Hal ini terjadi karena STKS mengandung senyawa-senyawa hidrofobik seperti holoselulosa, abu, pentosan, dan sebagainya [20]. Sementara itu sifat komposit berpengisi selulosa menghasilkan \% daya air yang tinggi. Hal ini dikarenakan sifat selulosa yang lebih hidrofilik. Dari Gambar 1 juga dilihat bahwa $\%$ penyerapan air pada 24 jam pertama yang tertinggi untuk pengisi serat tandan kosong sawit dan selulosa berada pada rasio 80/20, kemudian diikuti rasio $85 / 15$, rasio 90/10 dan terakhir pada rasio 95/5. Hal ini disebabkan komposisi kedua pengisi yang paling banyak berada pada rasio $80 / 20$ sehingga sedikit memperbesar sifat hidrofilik dari komposit. Adapun poliester tidak jenuh (UPR) juga menyerap air pada 24 jam pertama namun setelah itu penyerapan air tidak lagi begitu signifikan. Hal yang menyebabkan matriks UPR masih menyerap air dikarenakan UPR memiliki gugus fungsi ester yang masih mengikat air [18]. Penyerapan air oleh suatu komposit disebabkan karena adanya ikatan hidrogen yang terbentuk antara gugus $\mathrm{OH}$ pada serat alam dan air. Gambar 2 berikut menunjukkan penyerapan air oleh pengisi serat alam. Molekul air pertama kali diserap pada gugus hidrofilik dalam 
serat dan setelah itu molekul air yang lain juga mulai tertarik ke gugus hidrofilik yang lain sehingga nantinya molekul-molekul ini dapat membentuk suatu lapisan di atas molekul air yang telah terserap [18].

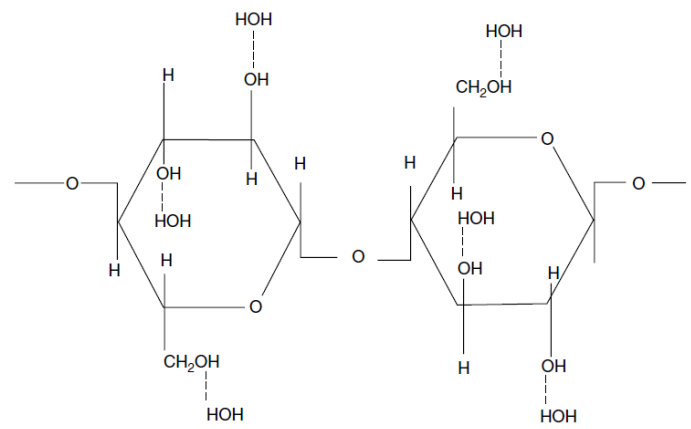

Gambar 2. Pengikatan Molekul Air oleh Serat Alam [18]

\section{Perhitungan Fraksi Volume Serat}

Kandungan bahan pengisi berupa serat tandan kosong sawit dan selulosa berpengaruh terhadap fraksi volume serat dalam komposit. Tabel 1 menunjukkan pengaruh nilai kandungan bahan pengisi terhadap fraksi volume serat pada komposit yang dihasilkan.

Tabel 1. Kandungan Bahan Pengisi Terhadap Fraksi Volume Serat Pengisi

\begin{tabular}{|c|c|c|}
\hline $\begin{array}{c}\text { Rasio } \\
\text { UPR:STKS/ } \\
\text { UPR: Selulosa }\end{array}$ & $\begin{array}{c}\text { Fraksi Volume } \\
\text { Serat STKS }\end{array}$ & $\begin{array}{c}\text { Fraksi Volume } \\
\text { Selulosa }\end{array}$ \\
\hline $95: 5$ & 0,068 & 0,074 \\
$90: 10$ & 0,134 & 0,144 \\
$85: 15$ & 0,197 & 0,211 \\
$80: 20$ & 0,258 & 0,274 \\
\hline
\end{tabular}

Nilai di atas menunjukkan bahwa semakin besar kandungan bahan pengisi pada komposit maka fraksi volume serat pada komposit juga akan semakin meningkat. Fraksi volume serat menunjukkan adanya hubungan dengan daya serap air komposit, dimana keduanya meningkat dengan meningkatnya kandungan bpengisi. Karakteristik daya serap air oleh serat alam berlangsung dengan mekanisme umum dimana ketika komposit berada dalam suatu lingkungan yang lembab, maka serat alam tersebut akan mengalami proses pembengkakan (swelling). Adapun akibat dari proses pembengkakan serat ini, maka akan terjadi perengkahan mikro (micro cracking) pada matriks poliester tidak jenuh yang rapuh. Kandungan selulosa yang bersifat hidrofilik berkontribusi terhadap penetrasi air ke daerah interfasa melalui rengkahan mikro sebagai akibat dari pembengkakan serat. Begitu rengkahan mikro menjadi begitu aktif maka kapilaritas dan aliran molekul air akan terjadi sepanjang interfasa matriks-serat dan terjadi proses difusi dalam matriks curah (bulk) [5].

\section{Kesimpulan}

Semakin meningkatnya kandungan bahan pengisi dalam suatu komposit maka daya serap air pada komposit tersebut akan semakin besar. Daya serap air untuk komposit UPR berpengisi selulosa lebih besar dibandingkan penyerapan air untuk komposit UPR berpengisi serat tandan kosong sawit. Semakin meningkatnya kandungan bahan pengisi dalam suatu komposit maka fraksi volume serat pada komposit tersebut akan semakin besar.

\section{Daftar Pustaka}

[1] Amin A. M., Pengembangan Proses Pembuaan Selulosa Asetat dari Pulp Tandan Kosong Sawit Proses Etanol. Tesis Magister, Institut Teknologi Bandung. 2000.

[2] Chee P.E., Talib, R.A., Yusof, Y.A., Chin, N.L., Ratnam, C.T., Khalid, M., Chuah, T.G., "Mechanical and Physical Properties of Oil Palm Derived Cellulose-LDPE Biocomposites as Packaging Material". International Journal of Engineering and Technology. Vol 7, No.1 hal 26-32. 2010.

[3] Davallo M., Pasdar H., Mohseni M., Mechanical Properties of Unsaturated Polyester Resin. International Journal of ChemTech Research Vol.2 (4) 2113-2117. 2010.

[4] Deepa B., Pothan, L.A., Mavelil-Sam, R., Thomas, S., Structure, Properties and Recyclability Of Natural Fibre Reinforced Polymer Composites. Recent Developments in Polymer Recycling, 2011: 101-120.

[5] Dhakal, H.N., Zhang, Z.Y., Richardson, M.O.W., Effect of water absorption on the mechanical properties of hemp fibre reinforced unsaturated polyester composites". Journal of Composites Science and Technology. Diakses 20 Juni 2012 dari Sciencedirect Elsevier. http://www.sciencedirect.com/science/journal /. Diakses pada 20 April 2012. 2006

[6] Imoisili P.E., Etiobhio B.W., Ezenwafor. T.C., AttahDaniels B.E., Olusunle S.O.O., Physiochemical Analysis of Cocoa Pod and its Effect as a Filler in Polyester Resin Composite. International Journal of Science and Technology Vol.2 (1) 89-93. 2013.

[7] Indexmundi, Palm Oil Production by Country in 1000 MT. http: www.indexmundi.com. Diakses 18 Juni 2012 dari Indexmundi. 2011.

[8] Khalil H.P.S., Bhat, I.B., Sartika, M.Y., "Degradation, Mechano-Physical, And Morphological Properties of Empty Fruit Bunch Reinforced Polyester Composites". BioResources 5(4) 2010 : 2278-2296.

[9] Lokantara P., Suardana N.P.G., Studi Perlakuan Serat Serta Penyerapan Air Terhadap Kekuatan Tarik Komposit Tapis 
Kelapa/Polyester. Jurnal Ilmiah Teknik Mesin CakraM Vol.3 No.1, April 2009 (4956).

[10] Mathew, L., "Development of High Performance Polymer Nanocomposites Using Cellulose Nanofibrils From Isora Fibres: - A Wood Substitute". Department of Chemistry. Newman College, Thodupuzha, Kerala. 2009.

[11] Matty F.S., Al-Kafaji, J.K., Badri, D.H., "Preparation and Characterization of Unsaturated Polyester Material Blended With Cellulose and With Ethyl Cellulose". Eur.Chem. Bull.2(7), 477-480. 2013.

[12] Megat M.H., Abdalla, F.H., Sapuan, M.S., Sahari, B.B., Determination of Volume Fraction Values Of Filament Wound Glass and Carbon Fiber Reinforced Composites. ARPN Journal of Engineering and Applied Sciences Vol.3 (4). 2008.

[13] Musa B.H., Nassif R.A., Hadi E.M., Study of the Mechanical Properties for Unsaturated Polyester Reinforced By Natural Fibers. Journal of Al-Nahrain University Vol.13 (3) 65-68. 2010.

[14] Nakagaito, A.N., Sato, S., Sato, A., Yano, H., "Cellulose Nanofiber-Reinforced Unsaturated Polyester as a Potential Substitute for Glass Fiber-Reinforced Plastics". Research Institute for Sustainable Humanosphere, Kyoto University, Japan. 2010.

[15] Noorshashillawati A.B.M, (2007). Synthesis, Characterization And Properties of The New Unsaturated Polyester Resins For Composite Applications. Master Thesis, Universiti Sains Malaysia.

[16] Porwanto D.A., Karakterisasi Komposit Berpenguat Serat Bambu dan Serat Gelas
Sebagai Alternatif Bahan Baku Industri. Tugas Akhir, Jurusan Teknik Fisika FTI ITS Surabaya. 2011.

[17] Prasad A.V.N., Rao, K.M., Nagasrinivasulu, G., Mechanical properties of banana empty fruit bunch fibre reinforced polyester composites. Indian Journal of Fibre \& Textile Research. 2009, Vol.34. pp.162-167

[18] Ray D., Rout, J., Thermoset Biocomposites. Dalam Mohanty, A.K., Misra, M., Drzal, L.T., Natural Fibers, Biopolymers, And Biocomposites. CRC Press : U.S.A. 2005.

[19] Salmah H., Marliza M., Teh P.L., Treated Coconut Shell Reinforced Unsaturated Polyester Composites. International Journal of Engineering \& Technology IJET-IJENS Vol.13 (2) 94-103. 2013.

[20] Sulhatun, Pemanfaatan Tandan Kosong Kelapa Sawit Sebagai Sumber Lignin. Tesis Magister, Sekolah Pascasarjana. USU. Medan. 2005.

[21] Waigaonkar S., Babu, B.J.C., Rajput, A., Curing Studies of Unsaturated Polyester Resin in FRP Products. Indian Journal of Engineering \& Material Sciences. 2011, Vol 18.hal. 31-39. 